\title{
A Pilot Study Assessing Attitudes toward Finance among Italian Business Students
}

\author{
Elisa Bocchialini ${ }^{1} \&$ Beatrice Ronchini ${ }^{1}$ \\ ${ }^{1}$ Department of Economics and Management, University of Parma, Parma, Italy \\ Correspondence: Elisa Bocchialini, Department of Economics and Management, University of Parma, via J.F. \\ Kennedy 6, 43126, Parma, Italy. E-mail: elisa.bocchialini@unipr.it
}

Received: July 11, 2019

Accepted: August 10, 2019

Online Published: September 5, 2019

doi:10.5539/ijbm.v14n10p44

URL: https://doi.org/10.5539/ijbm.v14n10p44

\begin{abstract}
Exploring 'attitude toward finance' as a factor predicting financial literacy is a new area of inquiry in academic literature. This study is a preliminary investigation of attitudes toward finance among a sample of students in higher education in Italy. It uses ten focus group discussions as data collecting method. Respondents are a total of 98 learners attending the Faculty of Business and Economics in a large University in northern Italy, majoring in the areas of Finance, Accounting, or Marketing. The aim of this study is to assess the state of the art of the beliefs, feelings and self-perceptions of the target group regarding financial matters and practices, and to generate a questionnaire to measure attitudes toward finance in future quantitative studies. A Chi-Square analysis is used to analyse the collected data and determine if there are significant associations between students' attitudes towards finance and characteristics like gender, level of study (first or second cycle degree) and faculty major. The research findings suggest that, even in a homogeneous cluster like our study population, the profile of attitude toward finance is not uniform. Overall, no significant differences are found between male and female students. Education level does not seem to significantly affect the construct either. However, the faculty major impacts on students' attitude toward finance. Policy implications and suggestions for further work are discussed.
\end{abstract}

Keywords: financial literacy, financial education, business students, financial attitudes, attitude toward finance

\section{Introduction}

Financial education of younger generations has become an issue of increasing societal concern and debate. Studies in different countries reveal that young people's financial skills are generally poor and this is true even of higher education students (OECD, 2017; Hasler \& Lusardi, 2017; Lusardi \& Wallace, 2013). Mixed evidence exists about the effects of the financial education programs for youth (Kasman, Heuberger \& Hammond, 2018; Miller, Reichelstein, Salas, \& Zia, 2014). However, as noted by the OECD (2013), future adults require "a sound financial culture and behaviors" which could also be a possible flywheel "of new habits in the rest of the population".

According to the literature, both cognitive and non-cognitive variables are relevant determinants of financial literacy. Among non-cognitive variables, motivation and attitude are believed to positively impact the construct. Attitude, in particular, is increasingly recognized as an important pillar of financial literacy (Arellano, Cámara \& Tuesta, 2018; OECD, 2016; Atkinson \& Messy, 2012). Bhushan and Medury (2014) suggest focussing on developing positive financial attitudes as a way of enhancing financial literacy among the wider population.

Studies of attitude cross the boundaries of a number of disciplines (Ahuja, 2017; Emmioğlu \& Yesim, 2012). Previous studies in academic fields apart from finance indicate attitudinal variables as a predictor for effective behavior and learning (Hannula, Di Martino, Pantziara, Zhang, Morselli, Heyd-Metzuyanim \& Goldin, 2016; Addabbo, Di Tommaso \& Maccagnan, 2015). Scholars have also clarified that attitude towards an object is different from attitude in itself, and also that attitude and aptitude are clearly not synonymous (Rao, 2004; Gauld \& Hukins, 1980; Gardner, 1975). The former has remained totally unexplored in the financial literacy research. Indeed, to the best of our knowledge, there are no previous studies exploring 'attitude toward finance' as a factor predicting financial literacy.

In this exploratory study, a focus-group discussion is used as a first attempt to gain familiarity with the construct as a key step to further investigating its role in attaining financial literacy. Our work is based on a 
three-dimensional model of attitude (Di Martino \& Zan, 2010) and we define attitude toward finance as a complex combination of a person's beliefs, emotions and self-concept associated with finance. The object of the attitude, 'finance', is intended as anything a person may hold in mind when speaking about finance, ranging from the field of study to a career path, including financial learning experiences, financial practices, and/or financiers. The population under study is young people, one of the most vital groups for further improvement of society. Specifically, the paper focuses on business students because they are presumed to be familiar with the attitude object under investigation. Their choice of academic pathway implies they should exhibit a more favourable attitude toward finance than average and, thus, should be more collaborative in discussing financial topics. The present study investigates attitudes toward finance within a business school, and thus within one discipline, comparing different majors in order to answer the following questions. Currently, what are business students' attitudes toward finance? What factors affect the construct? Do participants show distinct patterns across various majors or on the basis of gender and education level? What significant suggestions arise from the focus group sessions that will contribute to increasing the body of knowledge on this subject?

The research yields an interesting picture of the relationship between the target group and finance, and - given that extant literature does not discuss the topic - the insights are original. Our findings are that business students in our sample display significant different profiles of attitude toward finance on the basis of several variables. Their attitudes tend to differ in terms of direction (positive versus negative), base (more affectively-based attitudes vs. more cognitively-based attitudes) and strength (strong vs. weak, based primarily on affective/cognitive consistency). Comparisons between students from accounting, finance, and marketing, reveal that finance majors are most positive and are more likely to hold positive feelings or beliefs towards finance than the other groups. The findings suggest that while financial education initiatives are likely to focus on disseminating knowledge, many students in the sample are likely to have trouble with finance essentially due to non-cognitive factors, such as low self-confidence, negative point of view or adverse emotional disposition toward finance.

This paper is the first to date that attempts to assess people's attitudes toward finance by outlining a conceptual framework for the analysis. Each single attitude component is comprehensively examined in its interrelationships and under the umbrella of attitude. Second, this focus group study is used as a pilot to develop a questionnaire to measure the construct in a subsequent survey. The remainder of the paper proceeds as follows. Section 2 summarizes key issues arising from research about attitude in the financial field. Section 3 describes the methodological procedures and the tools used in our research, and Section 4 presents the results. Section 5 discusses and extends these results. Finally, Section 6 concludes, and policy implications and suggestions for further work are made.

\section{Literature Review}

From a social psychological perspective, attitudes have typically been defined as the durable mix of beliefs, emotional response and behavioural tendencies of a person related to a specific attitude object, which is evaluated with a degree of favour or disfavour (Rosenberg \& Hovland, 1960). Thus, attitude is considered a psychological tendency, an invisible phenomenon consisting of affective, behavioral and cognitive components (Eagly \& Chaiken, 1998). Among many existing models, the three-component model of attitudes, also known as the ABC model, is one of the most important and widely recognized (Rosenberg \& Hovland, 1960). It stresses the inter-linkages between knowing, feeling, and doing, and permits scholars to study how people think, feel and interact with a given attitude object.

Research on 'attitude' is still in its infancy in the financial literature, although it has recently been recognized as an important pillar of financial literacy, along with 'knowledge' and 'behaviour' (OECD, 2019; Atkinson \& Messy, 2012). "Attitudes help to provide a more nuanced picture of a person's capability" according the World Bank, (2013). There are however some difficulties in applying the tripartite characterization described above to the domain of financial education. One of the main problems is the inclusion of the behavioural dimension in the definition of attitude. In the PISA analytical framework (OECD, 2014), in fact, behaviour is a 'parent' to attitude, as one of its key components, and at the same time a 'sibling', because both behaviour and attitude are pillars of financial literacy. A conceptual conflict thus arises when researchers in financial education simply borrow the attitude construct from the context in which it appeared, i.e. social psychology. The social psychology construct in fact does not take into account the particular setting of financial education (see Figure 1). 


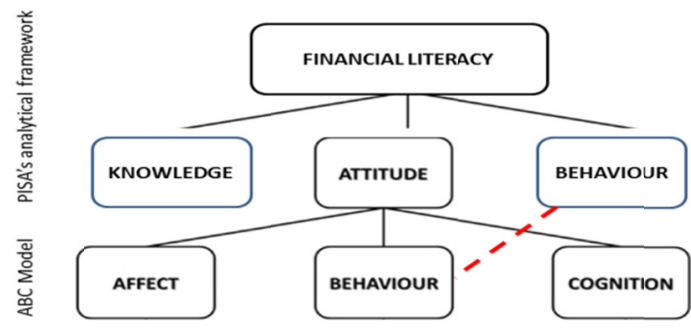

Figure 1. The challenges in assessing the attitude construct in the financial education field Source: Authors' own elaboration.

As a matter of fact, unresolved definitional and conceptual issues plague previous literature on financial education, where the extant research on attitude has developed in the absence of a clear and shared theoretical framework. There is little consistency in the way this complex and multidimensional construct is defined, operationalized and measured across studies.

In fact, several authors assign different connotations to the construct. For instance, Rai et al. (2019) define financial attitude "as personal inclination towards financial matters. It is an ability to plan ahead and maintain a savings account that matters". Bongini, Trivellato and Zenga (2013) frame financial attitude as "a way of looking at an issue or an object, a mental position or way of thinking about an issue (in our case financial matters)". In the same vein, Yap and colleagues (2016) emphasize that "attitudes mean a tendency to behave toward the object so as to keep or get rid of it; in addition, attitudes are also a set of beliefs that the object is either good or bad". Likewise, Garber and Koyama (2016) state that "attitudes are generally understood as concerning how people feel (emotional), although they may include some aspects relating to knowledge (beliefs) and to behavior (predispositions)", while Haque and Zulfiqar (2016) state that "financial attitude deals with ability to manage finances, interest of the individual in increasing financial knowledge, spending versus saving attitude and attitude toward taking risk while making an investment". Other researchers have eluded the problem of definition by avoiding a clear, explicit and ex ante definition of financial attitude, which however can be inferred a posteriori through the instruments used to assess it (Bhushan \& Medury, 2014).

Moreover, many researchers in financial education have focused on different attitude objects, including: money (Susilowati \& Latifah, 2017; Sundarasen \& Rahman, 2017); financial management (Rajna, Ezat, Junid \& Moshiri, 2011); financial capability (Prabhakar, 2014); financial market (Ford \& Kent, 2010); risk (Dohmen, Falk, Huffman, Sunde, Schupp, Wagner \& 2011); debt (Almenberg, Lusardi, Säve-Söderbergh \& Vestman, 2018; Agnew \& Harrison, 2015); investment (Brugiavini, Cavapozzi, Padula \& Pettinicchi, 2015; Becchetti, Caiazza, \& Coviello, 2013); credit and finances (Norvilitis \& Mendes-Da-Silva, 2013), just to name a few. It is not surprising that very mixed evidence exists about the impact of these different attitude variables on financial literacy.

When treating finance as an attitude object, the majority of scholars focus on the construct of financial attitudes (Paluri \& Mehra, 2016; Haque \& Zulfiqar, 2016) and, to a lesser extent, on financial aptitudes (Bongini et al., 2013). Conversely, the concept of attitudes toward finance, which is conceptually different from the other two (Rao, 2004; Gauld \& Hukins, 1980; Gardner, 1975), has so far not been explored as a variable in the financial literature. For example, Bhushan and Medury (2014) investigate the linkages between financial attitudes, financial behaviour and financial knowledge among a sample of 516 adults in India. They find that financial attitudes have a considerable effect on overall financial literacy. Bongini et al., (2013) survey 366 Italian business studies freshmen in order to explore whether they present dissimilar levels of financial literacy as a function of various characteristics, including 'financial aptitude'. They show that financial aptitude, expressed as "a particular inherent interest in financial matters", is definitely a predictor of financial literacy.

However, the absence of early systematic research on attitude toward finance has so far hindered a more comprehensive understanding of how the construct may influence financial literacy. Indeed, most previous studies in the financial domain have concentrated only on one single specific component of the concept. For example, some research focuses on the view of finance of a given target group (Dobni \& Racine, 2016; Driva, Lührmann \& Winter, 2016) or the emotional disposition toward finance of a particular segment of population (Grable, Heo \& Rabbani, 2015; Shapiro \& Burchell, 2012; Holden, 2010) or the financial self-confidence of a 
specific target audience (Palameta, Nguyen, Hui \& Gyarmati, 2016; Arellano, Cámara \& Tuesta, 2014). In other words, a number of studies have investigated certain single aspects of attitude toward finance in isolation, without including them in a single complete framework. In most studies, these single aspects are not explicitly seen as a dimension of the attitude toward finance or related to other components of the construct. To address this gap in the knowledge, this paper seeks to combine all constituent components in a single model. We believe that the study of the multidimensional construct 'attitude toward finance' can advance the state of the art more effectively than investigations into isolated beliefs or feelings related to finance.

\section{Methodology}

\subsection{Analytical Framework}

The theoretical framework used here is based on the "Three-dimensional Model for attitude" (TMA model), which serves as the starting point of our exploration (Di Martino \& Zan, 2010). It was originally created as a model for students' attitudes towards mathematics, but it has also recently been used to assess attitude in other fields (Coppola et al. 2012). With appropriate adjustments to fit financial education, the model features attitude towards finance in three closely interrelated dimensions: view of finance, emotional disposition towards finance, perceived competence in finance (see Figure 2) (Note 1).

The view of finance is the sum of one's perceptions, beliefs, mental representations, metaphorical images and associations related to 'finance' as an attitude object. Finance can be viewed as a discipline of study, as a daily practice for the financial well-being and as a possible career choice. Hence, a personal 'image of finance' can be summarised in statements such as the following. 'Finances (as a subject) is... (i.e.: difficult versus challenging; boring, cold, abstract and uncreative versus interesting; masculine versus gender-neutral or feminine; accessible versus unapproachable to non-experts). 'Financial education is ... (i.e.: 'useless' rather than 'very important for everyday life, work and opportunities'). Learning finance is ... (i.e.: 'a question of inherent natural ability' versus 'a question of dedication and hard work'). Financiers and bankers are ... (i.e.: 'greedy and immoral' or 'they play a critical role in channeling savings into productive investments'). Each individual has a personal image of finance presumably formed as a result of his or her own social experiences and which is likely to change through personal one-to-one interactions or under the external influence of socialization agents such as parents, media, peers and teachers. Emotional disposition toward finances is one's affective reactions of liking or disliking finance. Finally, perceived competence in finance indicates the self-beliefs that individuals hold regarding being able or unable to succeed in the financial domain.

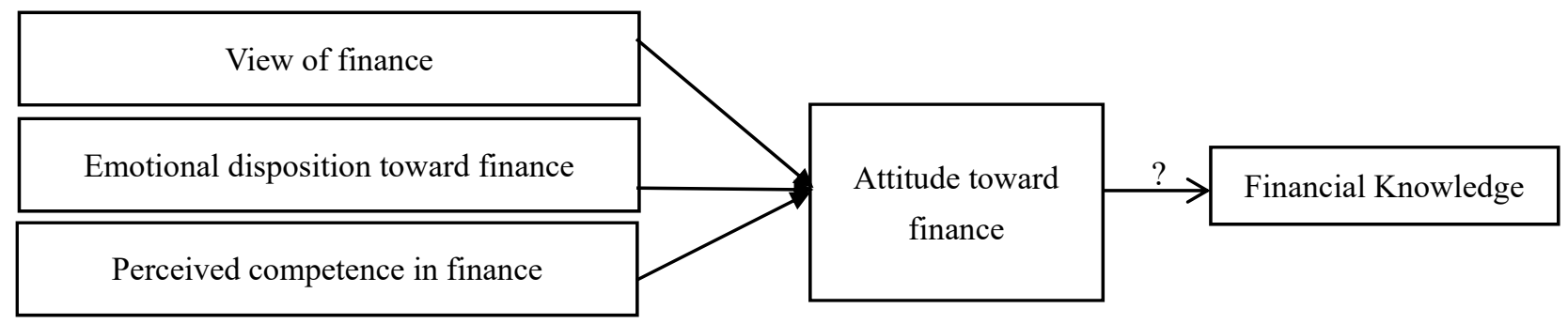

Figure 2. Conceptual Model of Attitude towards Finance

Source: Adaptation of TMA model by Di Martino and Zan (2010).

Thus, attitude toward finance depends on these three factors, and their interaction determines the degree to which finance is positively or negatively evaluated. Attitude toward finance can also range from weak to strong in intensity according to the degree of consistency among the three components. For example, a person having a negative vision, dysfunctional emotions towards finances and poor financial self-confidence will tend to have a strongly unfavourable attitude toward finance. But because the construct is multidimensional, it is possible to go beyond the simplistic positive/negative or favorable/unfavorable dichotomies. Different states of attitude, or 'attitude profiles' (Zan \& Di Martino, 2007) or 'triodes' (Jain 2014) can be built up. In other words, these researchers suggest that the combinations of the three dimensions can be used to build different types of attitude profiles of a person toward finance. As the concept consists of three elements and each can be either negative or positive, eight different combinations are possible (Table 1). Each triode is obtained through the combinations of the three dimensions and depends on the plus-minus sign $( \pm)$ of each single component. It is worth noting that of 
the eight possible different profiles, seven triodes "are 'negative' in some sense", because the model suggests that an attitude is positive only when all the three dimensions are positive. Each of the seven profiles of negative attitude towards finances is different depending on whether the adjective 'negative' refers to beliefs, emotions, perceived competence or to any two or all three at the same time (Zan \& Di Martino, 2014).

Table 1. Triode

\begin{tabular}{llll}
\hline TRIODE & VISION OF FINANCES & EMOTIONAL DISPOSITION & PERCEIVED COMPETENCE \\
\hline PPP & Positive & Positive & Positive \\
PPN & Positive & Positive & Negative \\
PNP & Positive & Negative & Positive \\
PNN & Positive & Negative & Negative \\
NPP & Negative & Positive & Positive \\
NPN & Negative & Positive & Negative \\
NNP & Negative & Negative & Positive \\
NNN & Negative & Negative & Negative \\
\hline
\end{tabular}

Source: Adaptation from Jain (2014).

\subsection{Method}

The aim of this research is to collect the narratives related to business students' view, feelings, and self-perceptions about the financial world in order to ascertain their perspectives on finances 'from the bottom' (Calder, 1977). The research seeks to identify their profile of attitude toward finance. To explore such a relatively new, complex and underexplored topic in literature, focus groups are widely believed to be an appropriate research method. In assessing attitudes, the use of non-traditional methods is widespread (Hannula et al., 2016; Ruffell, Mason \& Allen, 1998). In fact, the qualitative approach may provide a potentially richer source of data about beliefs and emotions, which are less accessible to quantitative methods. Moreover, this approach may allow respondents to spontaneously specify what they consider important on the subject and omit other information. Further, this method is also useful to shed light on their unconscious emotional reactions about finances and to capture the language young people use about these issues (Morgan \& Krueger 1998). Finally, focus group results, combined with critical literature reviews, will be used as a pilot to develop a questionnaire on a Likert scale for the survey part of the study. The results enable us to identify adequate answer categories for the close-ended questions and to define question wording, question order, format, as well as other aspects of research design (Lankshear, 1993). Items will include both affective and cognitive components of attitude used in this study (see Appendix A).

\subsection{Participants}

The target group of this research is a very specific segment of the youth population: people studying economic subjects in higher education. This is a frequently used convenience sample in financial literacy studies (Bongini, Trivellato \& Zenga, 2016; Wagland \& Taylor 2009). We purposely concentrate on students enrolled in an Italian Business School, on the assumption that having chosen their course, business students are more interested in financial matters and also more familiar with them. They are expected to be more collaborative than average during our focus group discussions. We also believe that their belonging to the same educational background gives rise to productive conversational dynamics and limits unnecessary conflict during focus group sessions. On the other hand, participant diversity in terms of age, gender, academic specialization and level of degree should avoid an excess of homogeneity which could flatten the group dynamics during discussion. Moreover, an investigation conducted exclusively on business students also offers the opportunity to examine whether gender differences in attitudes toward finances exist even among an educationally homogeneous sample of individuals, i.e. people pursuing an economic degree (Bongini et al., 2016).

Participants were recruited through fliers and e-mails which gave information about the purpose of the study, interview duration, and the deadline for volunteering. Participation was restricted to students majoring in the field of economics and was strictly voluntary. Finally, 98 business students agreed to participate in the study. See Table 2 for their characteristics:

- $64 \%$ were first cycle degree undergraduate students (Bachelor's degree) and 36\% were second cycle degree students (Master's degree); 
- $\quad 54 \%$ were female and $46 \%$ were male;

- $\quad 36 \%$ were enrolled in finance majors and $64 \%$ in business majors other than finance (mainly accounting and marketing).

The overall number of participants is comparable to the average amount of respondents in similar studies (Carlsen \& Glenton, 2011). Before the focus group met, a reminder notice was provided to volunteers. Focus group discussions were convened in Parma (Italy) between September 2015 and March 2018. Each session lasted approximately two hours.

In order to cultivate a positive atmosphere during the interviews, we included in each session people of the same cohort who hypothetically had similar familiarity with the topic being investigated. So ten groups were designed on the basis of the students' gender, age and curricula, with between six and thirteen members per group (Morgan \& Krueger, 1998). Given the nature and sensitivity of the topic - gender stereotypes and gendered financial role patterns remain widespread in the financial domain (Driva et al., 2016; Danes \& Haberman, 2007) - we initially aimed at separate sessions for males and females (homogenous focus groups) in order to create a more comfortable atmosphere and improve the quality of interaction. Three groups consisted of only female students and three groups of only male students. In this case, we assumed that males, who usually score higher on overconfidence and measured financial knowledge than women (Stolper \& Walter, 2017) would be more dominant in the conversation, hindering female students from freely expressing themselves. But finally four mixed gender groups were also set up in order to verify whether a heterogeneous focus group would have different dynamics from which to gather new insights, a more insightful discussion, and a wider range of positions. Early fears that male participants could dominate the discussion proved unfounded.

Table 2. Characteristics of focus group participants

\begin{tabular}{|c|c|c|c|c|c|}
\hline Group & No. Participants & Gender (no.) & Age, $y$ & Curricula (Note 2) & Level (Note 3) \\
\hline 1 & 10 & Female (10) & $19-22$ & $\frac{\text { Single Curriculum }}{\text { Economics and Finance (10) }}$ & First Cycle \\
\hline 2 & 11 & Female (11) & $19-31$ & $\begin{array}{l}\text { Mixed curricula } \\
\text { Economics and Marketing (7) } \\
\text { Business Administration (4) }\end{array}$ & First Cycle \\
\hline 3 & 6 & Female (6) & $19-21$ & $\begin{array}{l}\text { Single Curriculum } \\
\text { Economics and Finance (6) }\end{array}$ & First Cycle \\
\hline 4 & 10 & Male (10) & $21-26$ & $\begin{array}{l}\text { Mixed curricula } \\
\text { Economics and Marketing (4) } \\
\text { Business Administration (2) } \\
\text { Economics and Finance (4) }\end{array}$ & First Cycle \\
\hline 5 & 6 & Male (6) & $22-25$ & $\begin{array}{l}\text { Mixed curricula } \\
\text { Economics and Marketing (2) } \\
\text { Business Administration (2) } \\
\text { Economics and Finance (2) }\end{array}$ & First Cycle \\
\hline 6 & 9 & Male (9) & $20-26$ & $\begin{array}{l}\text { Mixed curricula } \\
\text { Economics and Marketing (1) } \\
\text { Business Administration (5) } \\
\text { Economics and Finance (3) }\end{array}$ & First Cycle \\
\hline 7 & 10 & $\begin{array}{l}\text { Female (5) } \\
\text { Male (5) }\end{array}$ & $23-27$ & $\frac{\text { Single Curriculum }}{\text { Finance and Risk Management (10) }}$ & Second Cycle \\
\hline 8 & 11 & $\begin{array}{l}\text { Female (5) } \\
\text { Male (6) }\end{array}$ & $19-27$ & $\begin{array}{l}\text { Mixed curricula } \\
\text { Economics and Marketing (8) } \\
\text { Business Administration (3) }\end{array}$ & First Cycle \\
\hline 9 & 12 & $\begin{array}{l}\text { Female (7) } \\
\text { Male (5) }\end{array}$ & $22-26$ & $\frac{\text { Single Curriculum }}{\text { Administration and Management (12) }}$ & Second Cycle \\
\hline 10 & 13 & $\begin{array}{l}\text { Female (9) } \\
\text { Male (4) }\end{array}$ & $23-27$ & $\frac{\text { Single Curriculum }}{\text { Trade and consumer marketing (13) }}$ & Second Cycle \\
\hline
\end{tabular}

Source: Authors' own elaboration. 


\subsection{Tools}

Focus group discussions were conducted using a semi-structured interview guide mainly inspired by Di Martino and Zan's (2010) theoretical framework and appropriately adapted to this context. The original model was adapted to financial education and reformulated in order to assess and compare each student's profile of attitude toward finance. The protocol (see Table 3) consisted of three parts exploring each item of the model: participants' view of finance (Questions 1, 2, and 3); their emotional disposal toward finance (Question 4), and their perceived competence in this field (Question 5).

Table 3. Discussion guide

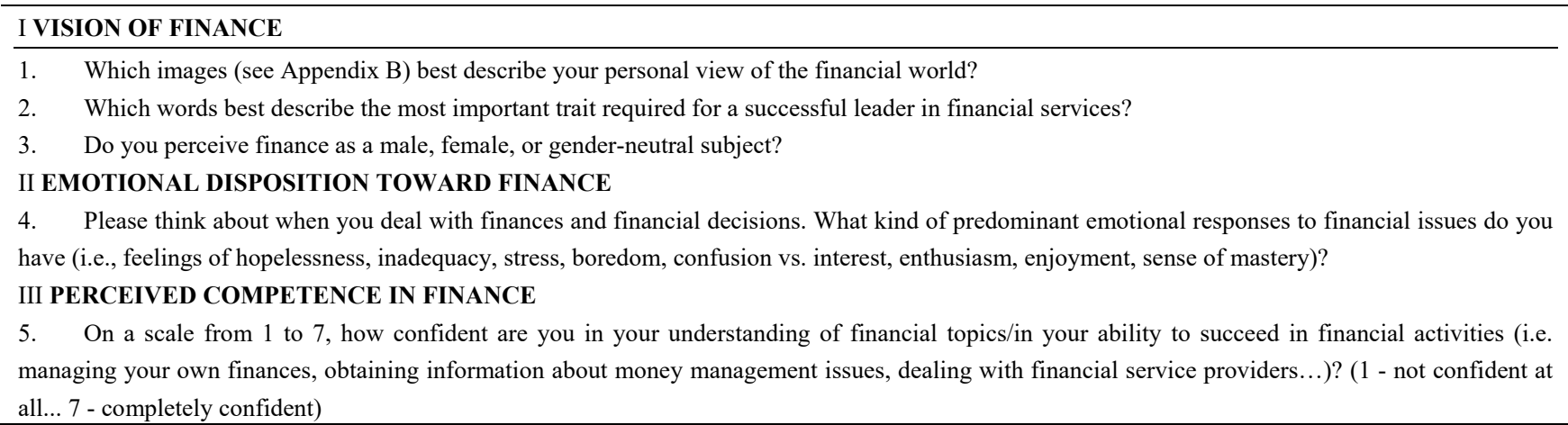

With the respondents' permission, the ten focus group sessions were recorded and transcribed. In order to systematically and iteratively identify the interpretative codes, a grounded theory approach was employed. The data were first investigated qualitatively to explore the meaning students gave to 'finance'. Then, in order to highlight the different profiles of attitude toward finance among the selected sample, we applied an algorithm which assigned a number to each open-ended response. A numerical array was established $v=(v 1, v 2$, v3) for each participant representing his/her view of finance; his/her emotional disposition and his/her perceived competence in this field - in brief his/her attitude profile (Albano \& Ascione, 2008). Transforming the coded qualitative data into summary variables made it possible to run statistical analysis, and test the research hypothesis. The data were also analyzed by quantitative methods to test for the strength of association between variables. Chi square tests of significance were used to ascertain the relationship between different demographic or personal factors (gender, level of higher education, major) on students' attitudes toward finance.

\section{Main Results}

\section{, What do business students think about 'finance'?}

Participants were first asked to select the one of the nine images shown in Appendix B which most closely matched their personal view of the financial world. A clear pattern of responses emerged.

Among female business students the most popular picture chosen was 'House of cards', implying that the financial system is perceived as an inherently unstable place, a world where if one bank fails, they all fail. Moreover, female participants were more likely than their male counterparts to see the financial market as an emotional place, hazardous, often immoral, a place for speculation purposes. However, the image that best represented personal vision of the financial word for male students was 'Dance now if you like'. This choice emphasized the volatility and uncertainty typical of financial markets. Most male students across the different age groups and majors, also saw the stock market as a wealth creating vehicle, an institution of vital importance in the broader political economy. Most of them also stressed the association between finance and statistics and mathematics.

\section{. What are the most important traits of a successful leader in financial services?}

When moderator asked participants to cite the key traits of a successful leader in financial services, the response pattern cut across the major groups of gender and age. Both female and male students cited hard skills such as rationality, expediency and numeracy as necessary for successful careers in finance. Intelligence and career-orientation were the traits most frequently cited as important for the ability to perform well in the sector, followed by dominance, ambition and charisma. These labels were essentially shared across the different age groups (faculty level) and gender. Interestingly, most of the qualities cited were stereotypically linked to 
masculinity, while several other features which may be useful for financial professionals, such as ethical/emotional capabilities, were largely underestimated by participants. However, the non-finance major students were more likely than average to depict financiers and bankers in a more stereotyped way. In their perceptions, leaders in financial services hold values and skills very different from their own (E.g.: "To me, financial professionals are self-entitled, greedy, astute and careerists; I see myself as 'different' from them!'). Conversely, postgraduate students of both genders enrolled in finance majors were less likely than other students to use stereotypical characteristics in describing the financial sector. They also hold a more positive view of financiers and bankers than other participants, in conjunction with a more favourable perception of the field of finance as a whole, of which they stressed the widespread societal impacts.

\section{- Do business students in the sample perceive finance as a male, female or gender-neutral subject?}

Given that finance and banking have historically been seen as a male domain in Italy, the moderator was particularly interested to see whether this traditional gender-stereotyped view of the field would be challenged by the focus group participants. Not surprisingly, only a minority of respondents stated that they considered finance as a female domain. Male students in fact associated finance with the gender neutral option more frequently, and 'masculine' was ranked second. Conversely, female students were more inclined to perceive finance as 'masculine', and for them 'gender-neutral' was ranked second. Like male students, most students enrolled on finance majors considered finance to be a neutral domain. Finally, like female students, students from non-financial backgrounds considered finance mainly a masculine domain. These gendered perceptions of finance probably reflect cultural models prevalent in Italian society, where men are still more likely than women to take responsibility for household financial decisions. They probably also reflect the typical media portrayal of the financial sector as a male-dominated environment. The absence of female financial role models also plays a role. The discussions however suggested that strict gender division in educational and professional spheres is a thing of the past. The vast majority of female participants said they didn't feel they were betraying cultural expectations of gender roles if they followed a financial major or took up a career in finance. Only a few girls were skeptical of the value of entering a financial profession that would require characteristics not perceived as fully consistent with femininity. Overall, most participants believed that nowadays finance is liked equally by boys and girls and is equally important for both genders as adults.

\section{- What emotional responses to financial issues do business students have?}

Across the sample, respondents nominated a wide range of feelings related to financial matters/practices. For example, most students who were not following a finance major curriculum self-reported affective states of relative disinterest and even anxiety, confusion and discomfort toward financial education. They perceived financial courses as difficult, particularly because of their quantitative nature, not creative and sometimes even boring. They stated a prior interest in other domains and confirmed that finance was not among their favourite subjects. Key elements underpinning this somewhat dysfunctional emotional response, and consequent low engagement with finance, involved the perceived difficulty of success in this area and finding financial literacy not pivotal to their future career. It is likely that a perceived close association between finance and maths, combined with low maths aptitude, also contributed to their feelings of detachment and disinterest toward the financial field. Not surprisingly, most of these students also stated they were reluctant to pursue a finance-related career, mainly because they didn't see bankers and other finance professionals as people who were intellectually similar or holding values similar to their own.

Conversely, postgraduate students enrolled on a finance major were more likely than other participants to consider finance as an interesting and enjoyable subject matter. Their strong personal interest in finance was the key driver of their decision to specialize in finance, for which they stated they had curiosity and enthusiasm. These respondents considered financial education a necessary part of their qualification portfolio and were convinced of the usefulness of financial education for both everyday life and their future career.

\section{How confident are business students in their ability to understand financial topics and to succeed as a} financial professional or in financial tasks?

When asked to what extent they believed in their own financial competence and in their own ability to succeed as a financial professional or in financial tasks, respondents showed significant heterogeneity in their responses, largely on the basis of their areas of academic specialization. Non finance-major participants were more likely than others to doubt their own talents to succeed in the financial domain. This appeared to be mostly due to an alleged lack of innate financial abilities and maths aptitude. Their stereotypical perceptions of financial professionals as very number orientated were stronger deterrents from specializing or pursuing a career in finance than the fact that the financial professionals were perceived as having low levels of ethics and creativity. 
A very different picture emerged among participants specializing in finance. Irrespective of gender, these postgraduate students trusted their own capabilities to succeed educationally and professionally in the field, and considered finance as a difficult but attractive subject matter. Most of them stated that their success was due to a mix of innate ability, maths aptitude, effort and perseverance. It also emerged that their achievement in finance had both internal and external sources. They confirmed a genuine interest in financial education, but they were also motivated by a mix of external rewards, such as job availability in finances, long-term salary opportunities and the perceived prestige of the financial profession. Some female students also cited the non-monetary implications, or psychological costs, of a career in finance, notably in terms of sacrifices in their personal lives and difficulties in adapting to a predominantly male culture.

\section{Discussion}

The focus group interview transcripts were analysed using the most appropriate statistical test. Due to the limited and primarily qualitative (nominal) nature of the available data, simple statistical frequencies and chi-square analyses were used to analyse participants' responses, considering a P-value of $<0.01$ as the cut-off level for significance. In order to discover whether there was any significant association between attitude toward finance of the respondents and certain personal variables (current faculty level, faculty major, gender), the following null hypothesis were explored in the study:

1. Responses to focus group questions do not differ significantly based on respondent gender (male versus female).

2. Responses to questions do not differ significantly based on respondent's current level of study (first or second cycle degree).

3. Responses to questions do not differ significantly based on respondent's faculty major (academic specialization - finance major versus non-finance major).

The results are presented in the following tables (Tables 3 and 4).

Table 3. Measures of association between "Attitude to Finance" (ATF) and other variables

\begin{tabular}{llll}
\hline & $\begin{array}{l}\text { Gender } \\
\text { (male vs. female) }\end{array}$ & $\begin{array}{l}\text { Faculty Level } \\
\text { (first cycle vs. second } \\
\text { cycle) }\end{array}$ & $\begin{array}{l}\text { Faculty Major } \\
\text { (finance vs. no finance) }\end{array}$ \\
\hline $\begin{array}{l}\text { Attitude toward finance (ATF) } \\
\text { Phi Coefficient }\end{array}$ & 0.052 & 0.141 & $0.519^{* * *}$ \\
Cramer's $V$ & 0.052 & 0.141 & $0.519^{* * *}$ \\
\hline
\end{tabular}

The probabilities were calculated based on the Pearson $\chi 2$ test and the Likelihood Ratio test (or G method).

The statistical significance is indicated by means of asterisks:

$* * *$ - statistical significance at $1 \%$;

** - statistical significance at 5\%;

* - statistical significance at $10 \%$. 
Table 4. Measures of association between "Attitude toward Finance" components - (1) View of finance, (2) Emotional disposition toward finance, (3) Perceived competence in finance - and variables

\begin{tabular}{llll}
\hline & $\begin{array}{l}\text { Gender } \\
\text { (male vs. female) }\end{array}$ & $\begin{array}{l}\text { Faculty Level } \\
\text { (first cycle vs. second } \\
\text { cycle) }\end{array}$ & $\begin{array}{l}\text { Faculty Major } \\
\text { (finance vs. no finance) }\end{array}$ \\
\hline $\begin{array}{l}\text { View of finance } \\
\text { Phi Coefficient }\end{array}$ & 0.050 & 0.126 & $0.550^{* * *}$ \\
Cramer's $V$ & 0.050 & 0.126 & $0.550^{* * *}$ \\
Image & & & $0.302^{* * *}$ \\
Phi Coefficient & 0.137 & 0.003 & $0.302^{* * *}$ \\
Cramer's $V$ & 0.137 & 0.003 & $0.244^{*}$ \\
Trait & & & $0.244^{*}$ \\
Phi Coefficient & 0.039 & 0.024 & $0.215^{*}$ \\
Cramer's $V$ & 0.039 & 0.024 & $0.215^{*}$ \\
Gender & & & $0.475^{* * *}$ \\
Phi Coefficient & 0.012 & 0.086 & $0.475^{* * *}$ \\
Cramer's $V$ & 0.012 & 0.086 & $0.435^{* * *}$ \\
Emotional disposition toward finance & & & $0.435^{* * *}$ \\
Phi Coefficient & & $0.264^{*}$ & \\
Cramer's $V$ & 0.122 & $0.264^{*}$ & \\
Perceived competence in finance & 0.122 & 0.095 & \\
Phi Coefficient & & & \\
Cramer's $V$ & $0.235^{* *}$ & $0.235^{* *}$ & \\
\hline
\end{tabular}

The probabilities were calculated based on the Pearson $\chi 2$ test and the Likelihood Ratio test (or G method).

The statistical significance is indicated by means of asterisks:

*** - statistical significance at $1 \%$;

** - statistical significance at 5\%;

* - statistical significance at $10 \%$.

Using a Chi square to test association between variables, we found that:

- Null Hypothesis 1 was supported. As shown in Table 3, in our research sample there was no significant association between the overall attitude toward finance of the respondents and their gender. The chi-square test revealed no link between response category and gender. Gender did not seem to be a decisive variable to explain the general level and the profile of students' attitude; no evidence was found that gender influences overall attitude toward finance. Contrary to the widely-held view, and our own supposition, that women have a less positive attitude towards finance than men, we found no evidence for this difference in our (educationally) homogeneous sample of business students. Our respondents did not show distinct patterns of attitude across gender, and women and men reported similar attitudes toward finance. In fact, the positions of male and female students were similar on several issues. It appears that in our research sample, students' common educational background was in fact stronger than gender issues, as has been found in previous research on financial literacy (Bongini et al., 2016). Table 4, showing the individual components of attitude, reveals that gender did not predict the view of finance. Neither did emotional disposition. There was however evidence of association between the gender and the perceived competence in finance at the 5\% significance level. This result was consistent with the findings of several previous studies documenting the phenomenon of female lack of self-confidence in finance (Bucher-Koenen, Lusardi, Alessie, \& Van Rooij, 2017).

- Null Hypothesis 2 was supported. The two categorical variables - overall attitude toward finance and faculty level - were independent: no significant relationship existed in the sample between a student's attitude profile, except for the 'emotional disposition toward finance' component and level of study. As shown in Table 3, there were no attitude differences between undergraduate (First cycle/Bachelor's) compared with the 
postgraduate students (Second cycle/Master's). In fact, first cycle degree students did not differ significantly second-cycle degree students in terms of overall attitude, in their view of finance or in perceived competence in finance. Level of study however appears to impact more on their 'emotional disposition toward finance', as shown in Table 4. This component of attitude tended to change over the course of a degree program. It could be hypothesized that progress in studies, and in terms of age, affects the emotional disposition of a student. This improvement in emotional response toward finance could be a result of increasing familiarity with the attitude object gained during their studies.

- Null Hypothesis 3 was rejected. The two categorical variables - overall attitude toward finance and the faculty major (or academic specialty/ students' specialization area) - were dependent. The chi-square test indicated that there was a statistically significant relationship between major and general attitudes toward finance. There was statistical significance in all dimensions of the construct, and the major seemed to be the decisive variable in explaining the general level and profile of students' attitude. In fact, our focus group respondents definitely showed distinct patterns of attitude across majors: finance majors definitely had more positive attitudes than average. Compared to other participants, they believed more strongly that they would succeed academically and professionally in the financial area and recognized the societal value of the financial services industry. These students also thought that this career area met their job/life aspirations. Moreover, they tended to feel themselves aligned with the typical traits, skills, and values of financial professionals and perceived themselves as potential members of the financial community. They seemed to have a better understanding of the importance of financial education in their future career and everyday life. They were also more likely to experience positive affective reactions such as interest in finance and enjoyment of learning finance. Unfortunately, these claims are not corroborated by any previous evidence, given the gaps in current knowledge in the area of study.

Briefly, our results reveal that the current faculty major is the only variable significantly related to students' attitude toward finance, while the other two factors tested - gender and faculty level - are not significantly related to attitude toward finance, although they may be related to individual components of it.

\section{Conclusions}

This exploratory paper, based on the focus group discussion technique, describes what a sample of Italian business students think and feel about 'finances' as an attitude object. The study is designed to evaluate the overall attitude of business students towards finance and to identify variables affecting the students' attitude in terms of gender, students' major, and level of degree. Results of focus group discussions were also used to design a questionnaire which will be used for subsequent quantitative investigation of the topic.

About one hundred business students across several majors (accounting, finance, management and marketing) were considered a good laboratory in which to begin exploring the issue. Thanks to their affinity and familiarity with the fundamental disciplines of business, finance included, these study participants should provide a free flowing, open and sincere discussion around the research problem. Thus, the participants included in this study should help to better define the topic as well as alternative options to be included in a questionnaire.

The research provides several original insights about the type of response that the social stimulus 'finance' activates in the research sample at both cognitive and emotional levels. First, we expected to find a similar and essentially positive profile of attitude toward finance in our target group, but we did not. Our findings clearly indicate that the level and profile of attitude is not uniform throughout the sample.

In sum, we find a statistically significant association between students' major and our measure of overall attitude toward finance. A chi square comparison shows that a significantly higher percentage of finance major students show positive attitudes toward finance, compared to students currently enrolled in majors other than finance. In comparison with students of non-finance-related subjects, finance-oriented students (i.e. business students opting to specialize in finance at first or second cycle degree level) show a higher financial self-efficacy, a better emotional response and a more optimistic conception of finance as a sector, practice or subject of study. Non-finance oriented students are weaker in both areas of affective commitment toward finance and financial self-confidence. Regardless of gender, they tend to be less behaviourally, emotionally and cognitively engaged with finance. For other aspects, irrespective of gender and faculty cycle, attitudes toward finance appear similar across the sample. In line with past studies, female students in the sample are found to have lower self confidence in finance than their male counterparts, while the business first cycle students tend to show a lower emotional disposition toward finance than second cycle students.

The present paper has certain limitations. First, because of the small sample size and the qualitative nature of the study, it is not possible to generalize the findings to the public at large. Moreover, selection bias, social 
desirability bias and researcher bias are further possible methodological concerns. An additional limitation is that the study provides information only about business students, a very specific portion of the youth population. A further limitation has to do with the fact that this exploratory study starts from the suggestion that attitude toward finance may be involved in financial achievement, but this has yet to be proved. We do not measure participant levels of financial knowledge, so can offer no insight into the real link between attitude toward finance and financial knowledge. It is hoped that this unanswered question will be the subject of future studies using the theoretical characterization of the construct made here.

Despite these limitations, the present study contributes to the literature in several ways. First, it addresses a neglected issue, an underexplored theme in literature: the concept of attitude toward finance, which differs both from the commonly-used financial attitude concept and from the less-well-known financial aptitude construct. Second, for the first time, a specific analytical framework borrowed from mathematic education is used to analyze attitude toward finance. Unlike previous studies, the determinants of the construct - beliefs, feelings and perceived competence in finance - are placed in a unified setting and under the umbrella of attitude. Third, the study investigates the relationship between the attitude to finance and certain variables including gender, academic cycle and academic specialty. Fourth, the paper also provides some valuable insights for the construction of an effective questionnaire to measure the attitude toward finance in further quantitative study (see Appendix A). Lastly, the findings of this investigation complement those of earlier studies in the financial literacy field and identify fruitful new areas of research. As a first step in bridging the existing research gap, further exploration using quantitative forms of inquiry is needed to investigate the attitudes toward finance of the wider population. The profile of attitude of the population in general may in fact diverge in different ways from those of our participants, who may even be a sort of outlier in this issue. More research is also needed to investigate the causal relationships between 'attitude toward finance' and financial knowledge, which is pivotal to educational policy (Garber \& Koyama, 2016). Further research is required to widen the view of scholars emphasizing the need for financial literacy initiatives capable of generating wider interest in financial matters and self-confidence (Arellano et al., 2018; Bucher-Koenen et al., 2016; Grohmann, 2016). Given that these elements such as interest and self-confidence are solely a specific part of the attitude construct, the challenge now is to create a composite measure of attitudes toward finances, and demonstrate whether a favorable attitude toward finance is, ex ante, a guarantee of successful financial literacy process and, ex post, one of the specific outcomes that financial education programs should develop in learners.

\section{References}

Addabbo, T., Di Tommaso, M. L., \& Maccagnan, A. (2015). Education Capability: A Focus on Gender and Science. Social Indicators Research, 112, 239-257.

Agnew, S., \& Harrison, N. (2015). Financial literacy and student attitudes to debt: A cross national study examining the influence of gender on personal finance concepts. Journal of Retailing and Consumer Services, 25, 122-129. https://doi.org/10.1016/j.jretconser.2015.04.006

Ahuja, A. (2017). Study of scientific attitude in relation to science achievement scores among secondary school students. Educational Quest. An International Journal of Education and Applied Social Sciences, 8(1), 9. https://doi.org/10.5958/2230-7311.2017.00002.2

Ajzen, I. (1991). The theory of planned behavior. Organizational Behavior and Human Decision Processes, 50, 179-211. https://doi.org/10.1016/0749-5978(91)90020-T

Albano, G., \& Ascione, R. (2008). E-learning and affective student's profile in mathematics. In The Future of Learning - Globalizing in Education 11th International Conference on Interactive Computer aided Learning. https://doi.org/10.3991/ijet.v3i1.755

Almenberg, J., Lusardi, A., Säve-Söderbergh, J., \& Vestman, R. (2018). Attitudes to Debt and Debt Behavior. NBER working paper 24935 . https://doi.org/10.3386/w24935

Arellano, A., Cámara, N. \& Tuesta, D. (2014). The effect of self-confidence on financial literacy. BBVA Research Working Paper, No 14/28, October, Madrid.

Arellano, A., Cámara, N., \& Tuesta, D. (2018). Explaining the Gender Gap in Financial Literacy: The Role of Non-Cognitive Skills. Economic Notes: Review of Banking, Finance and Monetary Economics, 47, 2-3; 495-518. https://doi.org/10.1111/ecno.12113

Atkinson, A., \& Messy F. (2012). Measuring Financial Literacy: Results of the OECD / International Network on Financial Education (INFE) Pilot Study, OECD Working Papers on Finance, Insurance and Private Pensions, No. 15, OECD Publishing, Paris. https://doi.org/10.1787/5k9csfs90fr4-en 
Becchetti, L., Caiazza, S., \& Coviello, D. (2013). Financial education and investment attitudes in high schools: Evidence from a randomized experiment. Applied Financial Economics, 23(10), 817-836. https://doi.org/10.1080/09603107.2013.767977

Bhushan, P., \& Medury, Y. (2014). An empirical analysis of inter linkages between financial attitudes, financial behavior and financial knowledge of salaried individuals. Indian Journal of Commerce and Management Studies, 5(3), 58.

Bongini, P., Trivellato, P., \& Zenga, M. (2013). Financial Literacy and Undergraduates: A Question of Aptitude? Retrieved from http://ssrn.com/abstract=2325316. https://doi.org/10.2139/ssrn.2325316

Bongini, P., Trivellato, P., \& Zenga, M. (2016). Business Students and Financial Literacy: When Will the Gender Gap Fade away? Journal of Financial Management Markets and Institutions, 3(1), 13-30.

Brugiavini, A., Cavapozzi D., Padula, M., \& Pettinicchi, Y. (2015). Financial Education, Literacy and Investment Attitudes. NETSPAR Academic Series, DP-06/2015-014. https://doi.org/10.2139/ssrn.2637878

Bucher-Koenen, T., Alessie, R., Lusardi, A., \& Van Rooij, M. (2016). Women, confidence, and financial literacy, Working Paper, Mimeo.

Bucher-Koenen, T., Lusardi, A., Alessie, R., \& Van Rooij, M. (2017). How financially literate are women? An overview and new insights. Journal of Consumer Affairs, 51(2), 255-283. https://doi.org/10.1111/joca.12121

Calder, B. J. (1977). Focus Groups and the Nature of Qualitative Marketing Research. Journal of Marketing Research, 14(August), 353-364. https://doi.org/10.1177/002224377701400311

Carlsen, B., \& Glenton, C. (2011). What about N? A methodological study of sample-size reporting in focus group studies. BMC Medical Research Methodology, 11-26. https://doi.org/10.1186/1471-2288-11-26

Coppola, C., Di Martino, P., Pacelli, T., \& Sabena, C. (2012), Primary teachers' affect: a crucial variable in the teaching of mathematics. Nordic Studies in Mathematics Education, 17(3-4), 101-118.

Danes S. M., \& Haberman, H. (2007). Teen Financial Knowledge, Self-Efficacy, and Behavior: A Gendered View". Financial Counseling and Planning, 18(2), 48-60.

Daskalogianni, K., \& Simpson, A. (2000). Toward a definition of attitude: the relationship between the affective and the cognitive in pre-university students. Proceedings of PME, 24(2), 217-224.

Di Martino, P., \& Zan, R. (2010). 'Me and maths': towards a definition of attitude grounded on students' narratives. Journal of Mathematics Teacher Education, 13(1), 27-48. https://doi.org/10.1007/s10857-009-9134-Z

Di Martino, P., \& Zan, R. (2011). Attitude towards mathematics: A bridge between beliefs and emotions. ZDM: The International Journal on Mathematics Education, 43, 471-482. https://doi.org/10.1007/s11858-011-0309-6

Dobni, D. M., \& Racine, M. D. (2016). Investors' image of the stock market: Antecedents and consequences. Financial Services Review, 25, 1-28.

Dohmen, T., Falk, A., Huffman, D., Sunde, U., Schupp, J., \& Wagner, G. G. (2011). Individual risk attitudes: Measurement, determinants, and behavioral consequences. Journal of the European Economic Association, 9(3), 522-550. https://doi.org/10.1111/j.1542-4774.2011.01015.x

Driva, A., Lührmann, M., \& Winter, J. (2016). Gender differences and stereotypes in financial literacy: Off to an early start. Economics Letters, 146, 143-146. https://doi.org/10.1016/j.econlet.2016.07.029.

Eagly, A.H., \& Chaiken S. (1998). Attitude structure and function. In D. Gilbert, S.T. Fiske, \& G. Lindzey (Eds.) The Handbook of Social Psychology (4th ed., pp.269-322). McGraw-Hill.

Emmioğlu, E., \& Yesim, C. (2012). Attitudes and achievement in statistics: A meta-analysis study. Statistics Education Research Journal, 11(2), 95-102.

Ford, M. W., \& Kent, D. W. (2009). Gender differences in student financial market attitudes and awareness: An exploratory study. Journal of Education for Business, 85(1), 7-12. https://doi.org/10.1080/08832320903217366

Garber, G., \& Koyama, S. M. (2016). Policy-effective Financial Knowledge and Attitude Factors. Working Papers Series, 430, Central Bank of Brazil, Research Department. 
Gardner, P. L. (1975). Attitudes to Science: A Review. Studies in Science Education, 2. https://doi.org/10.1080/03057267508559818

Gauld, C., \& Hukins, A. A. (1980). Scientific Attitudes: A Review. Studies in Science Education 7. https://doi.org/10.1080/03057268008559877

Grable, J., Heo, W., \& Rabbani, A. (2015). Financial Anxiety, Physiological Arousal, and Planning Intention. Journal of Financial Therapy, 5(2), 2. https://doi.org/10.4148/1944-9771.1083

Grohmann, A. (2016). The gender gap in financial literacy: income, education, and experience offer only partial explanations. DIW Economic Bulletin, 6, 46-47, 531-537.

Hannula, M. S., Di Martino, P., Pantziara, M., Zhang, Q., Morselli, F., Heyd-Metzuyanim, E., \& Goldin, G. A. (2016). Attitudes, Beliefs, Motivation and Identity in Mathematics Education: An Overview of the Field and Future Directions. (ICME-13 Topical Surveys). Cham: Springer International Publishing. https://doi.org/10.1007/978-3-319-32811-9

Haque, A., \& Zulfiqar M. (2016). Women's Economic Empowerment through Financial Literacy, Financial Attitude and Financial Wellbeing. International Journal of Business and Social Science, 7(3).

Hasler, A., \& Lusardi, A. (2017). The gender gap in financial literacy: A global perspective. Washington, DC: Global Financial Literacy Excellence Center.

Holden, K. (2010). The emotions and cognitions behind financial decisions: The implications of theory for practice. Center for Financial Security Working Paper, 10(4).

Jain, V. (2014). 3D Model of attitude. International Journal of Advanced Research in Management and Social Sciences, 3(3), 1-12.

Kasman, M., Heuberger, B., \& Hammond, R. A. (2018). Review of Large-Scale Youth Financial Literacy Education Policies and Programs. Brookings Institution. https://www.brookings.edu/wp-content/uploads/2018/10/ES_20181001_Financial-Literacy-Review.pdf

Lankshear A. J. (1993). The use of focus groups in a study of attitudes to student nurse assessment. Journal of Advanced Nursing, 18, 1986-89. https://doi.org/10.1046/j.1365-2648.1993.18121986.x

Lusardi, A., \& Wallace, D. (2013). Financial Literacy and Quantitative Reasoning in the High School and College Classroom. http://dx.doi.org/10.5038/1936-4660.6.2.1

Miller, M., Reichelstein, J., Salas, C., \& Zia, B. (2014). Can you help someone become financially capable? A meta-analysis of the literature. World Bank, Policy Research Working Paper, no. WPS 6745. Washington D.C.: World Bank. https://doi.org/10.1596/1813-9450-6745

Morgan, D. L., \& Krueger, R. A. (1998). The focus group kit. Thousand Oaks: Sage.

Norvilitis, J. M., \& Mendes-Da-Silva W. (2013). Attitudes toward credit and finances among college students in Brazil and the United States. Journal of Business Theory and Practice, 1(1), 132-151. https://doi.org/10.22158/jbtp.v1n1p132

OECD. (2013). Financial Education for Youth and in Schools: OECD/INFE Policy Guidance, Challenges and Case Studies. OECD Publishing, Paris.

OECD. (2014). PISA 2012 Results: Students and Money: Financial Literacy Skills for the 21st Century. (Vol. VI), PISA, OECD Publishing, Paris. https://doi.org/10.1787/9789264208094-en

OECD. (2016). OECD/INFE international survey of adult financial literacy competencies. OECD Publishing, Paris.

OECD. (2017). G20/OECD INFE report on adult financial literacy in G20 countries, OECD Publishing, Paris.

OECD. (2019). Financial Literacy Framewok. PISA 2018 Assessment and Analytical Framework. OECD Publishing, Paris. https://doi.org/10.1787/b25efab8-en

Palameta, B., Nguyen, C., Hui, T. S., \& Gyarmati, D. (2016). The link between financial confidence and financial outcomes among working-aged Canadians. The Social Research and Demonstration Corporation, Ottawa.

Paluri, R. A., \& Mehra, S. (2016). Financial attitude based segmentation of women in India: an exploratory study. International Journal of Bank Marketing, 34(5), 670-689. https://doi.org/10.1108/IJBM-05-2015-0073

Prabhakar, R. (2014). What are public attitudes towards financial capability? Evidence from focus groups in 
London. Policy Studies, 35, 131-146. https://doi.org/10.1080/01442872.2013.875143

Rai, K., Dua S., \& Yadav, M. (2019). Association of Financial Attitude, Financial Behaviour and Financial Knowledge Towards Financial Literacy: A Structural Equation Modeling Approach, FIIB Business Review, 8(1), 51-60. https://doi.org/10.1177/2319714519826651.

Rajna, A., Ezat, W. P. S., Junid, S. A., \& Moshiri, H. (2011). Financial Management Attitude and Practice among the Medical Practitioners in Public and Private Medical Service in Malaysia. International Journal of Business and Management, 6(8), 105-113. https://doi.org/10.5539/ijbm.v6n8p105

Rao, D. B. (2004). Scientific Attitude, Scientific Aptitude and Achievement. New Delhi: Discovery Publishing House.

Rosenberg, M. J., \& Hovland, C. I. (1960). Cognitive, affective and behavioural components of attitudes. In C. I. Hovland, M. J. Rosenberg, W. J. McGuire, R. P. Abelson \& J. W. Brehm, (Eds.), Attitude Organization and Change. New Haven, CT: Yale University Press.

Ruffell, M., Mason, J., \& Allen, B. (1998). Studying attitude to mathematics. Educational Studies in Mathematics, 35(1), 1-18. https://doi.org/10.1023/A:1003019020131

Shapiro, G. K., \& Burchell, B. J. (2012). Measuring financial anxiety. Journal of Neuroscience, Psychology, and Economics, 5, 92-103. https://doi.org/10.1037/a0027647

Skagerlund, K., Lind, T., Strömbäck, C., Tinghög, G., \& Västfjäll, D. (2018). Financial literacy and the role of numeracy-How individuals' attitude and affinity with numbers influence financial literacy. Journal of Behavioral and Experimental Economics 74: 18-25. https://doi.org/10.1016/j.socec.2018.03.004

Stolper, O.A., \& Walter A. (2017). Financial literacy, financial advice, and financial behavior. Journal of Business Economics, 87(5), 581-643. https://doi.org/10.1007/s11573-017-0853-9

Sundarasen, S. D. D., \& Rahman, M. S. (2017). Attitude towards money: Mediation to money management. Academy of Accounting and Financial Studies Journal, 21(1), 1-18.

Susilowati, N., \& Latifah, L. (2017). College Students Financial Management Behavior: An Empirical Study on The Mediating Effect of Attitude Toward Money. Advanced Science Letters, 23(8), 7468-7472. https://doi.org/10.1166/asl.2017.9500

Wagland, S. P., \& Taylor, S. T. (2009). When It Comes to Financial Literacy, Is Gender Really an Issue? The Australasian Accounting Business and Finance Journal, 3(1), 13-23.

World Bank. (2013). Making Sense of Financial Capability Surveys around the World, Washington DC 20433.

Yap, C. J. R., Komalasari, F., \& Hadiansah, I. (2016). The Effect of Financial Literacy and Attitude on Financial Management Behavior and Satisfaction. International Journal of Administrative Science \& Organization, 23(3) 140-146. https://doi.org/10.20476/jbb.v23i3.9175

Zan, R., \& Di Martino, P. (2007). Attitudes towards mathematics: overcoming positive/negative dichotomy. The Montana Mathematics Enthusiast, 157-168.

Zan, R., \& Di Martino, P. (2014). Students' attitude in mathematics education. In S. Lerman (Ed.), Encyclopedia of Mathematics Education (572-577). https://doi.org/10.1007/978-94-007-4978-8

\section{Notes}

Note 1. It should be noted that in this paper we adopt the perspective that attitude is composed of cognitive and affective components only, and that behavior is thus a consequence of attitude and not a constituent (Ajzen, 1991; Daskalogianni \& Simpson, 2000; Di Martino \& Zan, 2011). In the field of financial education, where the financial literacy construct includes attitude and behavior as key pillars, excluding the behavioral dimension from the definition of attitude makes it possible to avoid the inconsistency that behavior is a component of both attitude and financial literacy.

Note 2. In the university where focus group participants are enrolled, the degree courses are divided into different curricula which are specialized in terms of subject matter. These include: for the bachelor's degree, curriculum in Business Administration (CLEA), curriculum in Economics and Marketing (CLAM), curriculum in Economics and Finance (CLEF); for the master's degree, Administration and Management curriculum (ADA), curriculum Trade and Consumer Marketing (Trade), curriculum Finance and Risk Management (FRIM). 
Note 3. The first level corresponds to the bachelor's degree, and the second level corresponds to the master's degree.

\section{Appendix A}

\section{Survey: Student's Attitudes towards Finances}

Instructions/Directions: This inventory consists of statements on the following three components of the "attitude towards finances construct": View of finance, Emotional Disposition to finance, Perceived confidence in finance. There are no correct or incorrect responses. Please read each statement carefully and think about how you feel about each of them. For each of the statements, please indicate the extent of your agreement or disagreement by placing a tick $[\downarrow]$ in the appropriate box. Please answer every question according to the scale shown here: Strongly Agree (SA), Agree (A), Neutral/ Unsure (N), Disagree (D), or Strongly Disagree (SD). Thank you in advance for your responses and your time. All your answers will be kept confidential.

\begin{tabular}{llllll}
\hline SURVEY STATEMENTS & SA & A & N & D & S D \\
\hline View of finance & & & &
\end{tabular}

You can get along perfectly well in everyday life without financial education

Financial sector is not important for the advance of society and for country's development.

A strong financial background could help me in my professional life

I think bankers and financiers are neat people

Finance is mainly a male domain

Males are not naturally better than females in finances

It is important for women to be good at finance as well as men

It's hard to believe a female could be a genius in finances

Finance is equally liked from boys and girls

There is nothing creative about finances

Finance is a math-intensive subject

\section{Emotional disposition toward finance}

Attending finance lessons and doing financial activities is fun and stimulating to me

Finance is one of the my most dreaded subject

I really enjoy finance (i.e.: going to finance lessons/ talking to other people about finance/ trying to solve a new financial problem/ watching a finance program on television)

I consider finance to be dull and boring

Finances makes me feel uncomfortable and nervous

I have a good feeling toward finance

I would enjoy school more if there were no finance lessons. I experienced more anxiety in the finance class

\section{Perceived competence in finance}

My mind goes blank and I am unable to think clearly when doing finances

I'm at ease during financial courses/activities

If I do badly in finances it is usually because

- I am not naturally good at it.

- I did not work hard enough.

- I was unlucky.

- the work is too hard.

To do well at finances you have to:

- be clever and genetically gifted at it

- have math aptitude

- work hard

- be lucky

Source: Authors' own elaboration accordingly focus group sessions and literature review. 


\section{Appendix B}

The images of 'Finance' presented during the focus groups

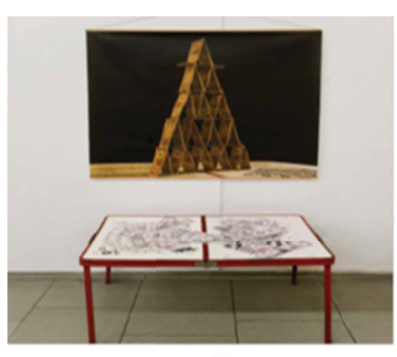

House of Cards

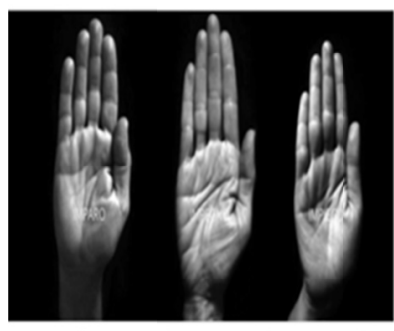

Learning, commitment, employment Ltd.

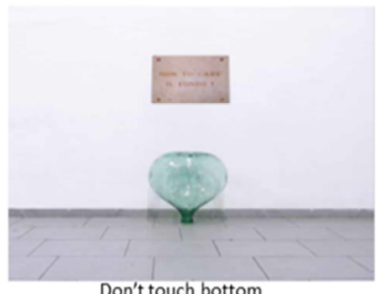

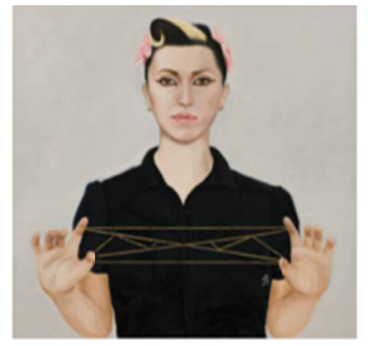

$\underline{\text { Strategies }}$

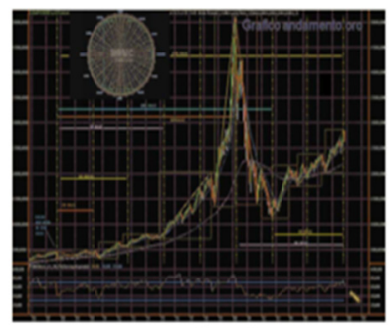

Dance if you like

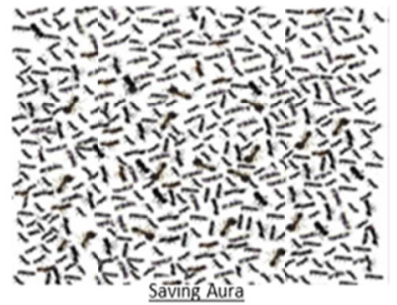

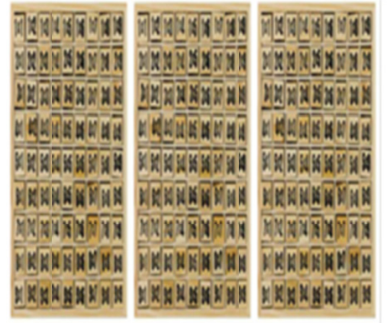

Calculation

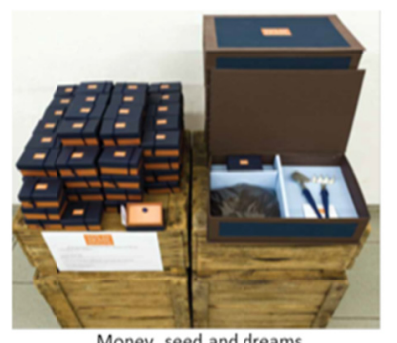

Money, seed and dreams

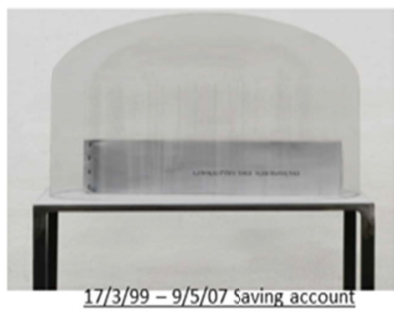

Source: Assogestioni and Accademia delle Belle Arti di Brera (2011) - Catalogue "Le metafore del risparmio".

\section{Copyrights}

Copyright for this article is retained by the author(s), with first publication rights granted to the journal.

This is an open-access article distributed under the terms and conditions of the Creative Commons Attribution license (http://creativecommons.org/licenses/by/4.0/). 